\title{
Assessment of the balance functions of children with Down syndrome attending selected paediatric clinical settings in Colombo district, Sri Lanka
}

\author{
*Hewa Haputhanthirige Nadeesha Kalyani ${ }^{1}$, Jithangi Wanigasinghe ${ }^{2}$
}

Sri Lanka Journal of Child Health, 2021; 50(2): 239-245

\begin{abstract}
Introduction: Down syndrome (DS) is known to exhibit specific balance problems due to deficits in the postural control system, hypotonia etc. Specific areas affected in the balance due to DS, and how it varies with age are yet to be found.
\end{abstract}

Objectives: To assess balance variations among children with Down syndrome in three different age groups ( 3 to 5 years, 6 to 9 years and 10 to 12 years) and to compare with age-matched healthy children.

Method: A descriptive study was conducted on 64 DS children. Paediatric Balance Scale (PBS) which is a 14-item validated scale assessing three different aspects of balance i.e. static, dynamic and transfer stability, was used. Each item was scored from 0-4. Scoring was performed by pre-trained investigators.

Results: Total PBS score for DS group (mean = 46.47) was less than that of normal $(\mathrm{N})$ children $($ mean $=54.58)(p=0.001)$. Out of three aspects, dynamic skills were highly affected, and among them, DS children exhibit lowest balance skills for standing on one foot (mean=1.47) and placing an alternate foot on a stool (mean=2.58). Balance skills showed an improvement with age (3 to 5 years $\mathrm{DS}=39.34, \quad \mathrm{~N}=52.83), \quad(6$ to 9 years $\mathrm{DS}=47.53, \mathrm{~N}=55.57)$, $(10$ to 12 years $\mathrm{DS}=50.95$, $\mathrm{N}=55.80$ ). Interestingly, the balance gap between normal and DS group seemed to narrow with age.

\begin{tabular}{l}
\hline${ }^{1}$ Lecturer, Department of Allied Health Sciences, \\
Faculty of Medicine University of Colombo. \\
Visiting Fellow, Queensland University of \\
Technology, ${ }^{2}$ Senior Lecturer and Consultant \\
Paediatric Neurologist, Department of Paediatrics, \\
Faculty of Medicine, University of Colombo \\
*Correspondence: nadeesha@med.cmb.ac.lk
\end{tabular}

https://orcid.org/0000-0002-1714-9915 (Keceived on 10 May 2020: Accepted after revision on 19 June 2020)

The authors declare that there are no conflicts of interest

Personal funding was used for the project.

Open Access Article published under the Creative Commons Attribution CC-BY (c) (i) License
Conclusions: In this study balance skills of DS children were significantly less than their age matched normal peers. The dynamic aspects of balance were more affected than the static or transfer stability. In DS balance skills showed an improvement with age.

DOI: http://dx.doi.org/10.4038/sljch.v50i2.9564

(Key words: Down syndrome, balance)

\section{Introduction}

Down syndrome (DS) has an incidence of around one in 800 births $^{1}$. Motor functional disabilities include delay in motor development, abnormal gait patterns, defects in postural control and lack of coordination $^{2}$. This includes prominent deficits in balance functions ${ }^{3}$. Balance is essential for successfully completing functional activities such as locomotor and manipulative skills ${ }^{4}$. In children with DS, balance is the hardest function to acquire ${ }^{4}$. Usually, DS children learn to walk around one year later than healthy infants ${ }^{5}$. Among gross motor skills, static and dynamic balance are the worst affected, in DS children ${ }^{6}$. The contributions to this include generalized hypotonia, ligament laxity, decreased muscle strength, persistent primitive reflexes and slowed reaction times during voluntary movement ${ }^{7}$.

Studies on balance functions in DS have shown that there is a significant correlation between motor functions and functional balance especially in the first three years of life ${ }^{4}$. Jung et al (2017) showed that unlike in normal children where the balance ability improved with growth, it remained low in DS children even after acquiring independent motor skills ${ }^{2}$. The low balance ability in DS children manifests as difficulties in walking backward, running, balancing on one foot, jumping from a step, jumping forward and kicking a ball ${ }^{8}$. It is evident that children with DS have problems in their balance functions but the understanding of how it changes with age is minimal. It is important to identify the age-related changes in balance in DS, as this knowledge would be beneficial for clinicians and therapists who are involved in enhancing DS children's static and dynamic balance skills to facilitate them to be efficient in schooling and daily living. With the aim of addressing this gap in the literature, the current 
paper demonstrates the balance variation among children with DS with increasing age, compared with age and sex matched healthy groups of children.

\section{Objectives}

To assess balance variations among children with DS in three different age groups (3 to 5 years, 6 to 9 years and 10 to 12 years) and to compare with age-matched healthy children.

\section{Method}

Design: Observational study

Setting: The DS group was recruited from a children's hospital and a special school, and the healthy group was recruited from a preschool and a leading school in the Colombo district, Sri Lanka. These assessments were performed when the children attended regular therapy sessions and schooling.

Participants: Participants were convenient samples of children with DS and age-matched healthy children (Control group: $\mathrm{CG}$ ) who were in the age range of 3 to 12 years. They were subdivided into three age groups, i.e. 3 to 5 years, 6 to 9 years, and 10 to 12 years. Sixty-four children with DS and 80 healthy controls participated in this study.

The inclusion criteria for the DS subjects were the presence of trisomy 21 determined by a physician, able to follow simple instructions, normal vision and hearing, the absence of co-morbidities, e.g. congenital heart defects, history of seizures, and independence in stance or ambulation ${ }^{9}$. The criteria to be selected to the CG were: absence of any orthopaedic or neurological disorder, no impairment of somatosensory, hearing, vestibular function and absence of any uncorrectable visual functions ${ }^{10}$. All participants provided written parental consent, in accordance with the ethical principles of the Declaration of Helsinki ${ }^{11}$.

Measures: The Paediatric Balance Scale (PBS) which is a modification of Berg's Balance Scale, was administered to children with DS and the CG to assess their balance functions. Developed in the United States, the PBS contains 14 items that assess functional balance in the context of the everyday life of children with mild to moderate motor impairment ${ }^{12}$. Each of the 14 tasks from the PBS was scored $0-4$ and a child who completed all the tasks could gain a maximum of 56 points $^{13}$. This scale has demonstrated reliability and ease of application ${ }^{14}$. The PBS also has excellent test-retest, interrater reliability, and intrarater reliability ${ }^{15}$. It is also capable of discriminating between children developing typically and children with mild, moderate and severe motor impairments ${ }^{16}$. In our study group, each test session lasted $10-20$ minutes. The PBS scores were calculated as static (PBS-static, six items), dynamic (PBS-dynamic, eight items), and total (PBS-total) ${ }^{17}$. Total PBS score was calculated by adding every single item in PBS (maximum value is 56 points). PBS dynamic and PBS static were calculated by adding each item and calculating the mean (maximum value for dynamic balance and static balance is 4 points each).

Procedure: The investigator visited the clinical settings, preschools and schools and a convenient sample was taken for each age group. The children who were willing to participate were recruited, and the recruitment was continued until the required sample was fulfilled. Prior to data collection, a simple questionnaire to identify demographic data was administered. The test was performed using equipment commonly found in the clinics and schools. Steady state and anticipatory balance activities of varying difficulty were performed with and without visual input. Item level scores were determined by the ability to perform the assessed activity. Visual and verbal cues were provided to ensure that the child understood the requested task.

Ethical Issues: Ethical clearance was obtained from the Ethics Review Committee of the Faculty of Medicine, University of Colombo, Sri Lanka (reference number: EC-15-138). Written informed consent was obtained from all the parents of the children with Down syndrome.

Statistical analysis: A power analysis, using the $G$ *Power software, was carried out to determine the required sample size for the $\operatorname{study}^{18}$. Preliminary data was drawn from a previous study (PBS score for normal children=48.5, $\mathrm{SD}=5.02$, PBS score for DS children=45.0, $\mathrm{SD}=7.72)^{4}$. Having referred to those population values, we estimated a sample size of 64 children per group, for a significance level alpha $=0.05$, power $=0.8$ and effect size $=0.53$. A multistep approach was used to handle the data, commencing with data screening and cleaning. This process consisted of the computation of summary scores and distribution checks. Descriptive analyses were reported for key variables and the demographic data. An ANOVA was performed to examine the differences between groups and age ranges with an interaction. Missing data was handled using multiple imputation method in Statistical Package for Social Sciences (SPSS). All statistical analyses were performed using SPSS version 23.0 with significance at $\mathrm{p}<0.05$.

\section{Results}

Sixty-four DS children and 80 normal healthy children participated in the study. The total PBS score for the DS group (mean=46.47) was significantly less than that of normal children of same age range $($ mean $=54.58)(\mathrm{p}=0.001)$ indicating that children with DS have a considerable decline in their balance functions. An ANOVA was 
performed in order to find the mean difference in the balance scores of DS and control groups and it is important to note that the difference became lesser with the advancement of age ( 3 to $5=12.889$, 6 to $9=8.037,10$ to $12=4.850$ ) (Table 1$)$. Table 2 presents the mean values for each balance activity included in the PBS for both Downs and normal children and it is noted that while dynamic skills were highly affected in the DS group, the lowest balance skills were reported for standing on one foot (mean=1.47) and placing an alternate foot on a stool (mean=2.58).

Table 1: Mean PBS score of Down syndrome group and control group with respect to different age groups

\begin{tabular}{|c|c|c|c|c|c|c|}
\hline $\begin{array}{c}\text { Age group } \\
\text { (years) }\end{array}$ & Status & Mean & Sample size & $\begin{array}{l}\text { Standard } \\
\text { deviation }\end{array}$ & $\begin{array}{c}\text { Mean } \\
\text { difference }\end{array}$ & p-value \\
\hline $3-5$ & $\begin{array}{c}\text { Down } \\
\text { Normal }\end{array}$ & $\begin{array}{l}39.94 \\
52.83\end{array}$ & $\begin{array}{l}18 \\
30\end{array}$ & $\begin{array}{l}6.27 \\
1.32\end{array}$ & 12.889 & 0.001 \\
\hline $6-9$ & $\begin{array}{c}\text { Down } \\
\text { Normal }\end{array}$ & $\begin{array}{l}47.54 \\
55.58\end{array}$ & $\begin{array}{l}26 \\
40\end{array}$ & $\begin{array}{l}3.81 \\
0.59\end{array}$ & 8.037 & 0.001 \\
\hline $10-12$ & $\begin{array}{l}\text { Down } \\
\text { Normal }\end{array}$ & $\begin{array}{l}50.95 \\
55.80\end{array}$ & $\begin{array}{l}20 \\
10\end{array}$ & $\begin{array}{l}3.52 \\
0.42\end{array}$ & 4.850 & 0.001 \\
\hline Total & $\begin{array}{c}\text { Down } \\
\text { Normal }\end{array}$ & $\begin{array}{l}46.47 \\
54.58\end{array}$ & $\begin{array}{l}64 \\
80\end{array}$ & $\begin{array}{l}6.25 \\
1.64\end{array}$ & 8.110 & 0.001 \\
\hline
\end{tabular}

$p<0.05$ significant, PBS: Paediatric Balance Scale

Table 2: Mean score for each item of Pediatric balance scale related to Down syndrome group and control group

\begin{tabular}{|c|c|c|c|c|c|c|c|c|c|c|c|c|c|c|c|c|}
\hline Status & Age & & $\begin{array}{l}\text { Sitring to } \\
\text { standing }\end{array}$ & $\begin{array}{l}\text { Standing } \\
\text { to sitting }\end{array}$ & Transfers & $\begin{array}{c}\text { Standing } \\
\text { unsupported }\end{array}$ & $\begin{array}{c}\text { Sitting } \\
\text { unsupported }\end{array}$ & $\begin{array}{c}\text { Standing } \\
\text { with } \\
\text { yes } \\
\text { closed }\end{array}$ & $\begin{array}{l}\text { Standing } \\
\text { with feet } \\
\text { together }\end{array}$ & $\begin{array}{c}\text { Standing } \\
\text { with one } \\
\text { foot in } \\
\text { front }\end{array}$ & $\begin{array}{c}\text { Standing } \\
\text { oa one } \\
\text { foot }\end{array}$ & $\begin{array}{c}\text { Turning } \\
360 \\
\text { degres }\end{array}$ & $\begin{array}{l}\text { Turning } \\
\text { to look } \\
\text { behind }\end{array}$ & $\begin{array}{l}\text { Retrieving } \\
\text { object } \\
\text { from foor }\end{array}$ & $\begin{array}{l}\text { Placing } \\
\text { alternate } \\
\text { foot on } \\
\text { stool }\end{array}$ & $\begin{array}{l}\text { Reaching } \\
\text { forward } \\
\text { with } \\
\text { outstretched } \\
\text { hand }\end{array}$ \\
\hline \multirow[t]{4}{*}{ Down } & $\begin{array}{l}10 \text { to } 12 \\
(\mathrm{~m}=20)\end{array}$ & $\begin{array}{l}\text { Mean } \\
\text { (SD) }\end{array}$ & $\begin{array}{l}3.95 \\
(0.22)\end{array}$ & $\begin{array}{l}4.00 \\
(0.00)\end{array}$ & $\begin{array}{l}3.90 \\
(0.31)\end{array}$ & $\begin{array}{l}4.00 \\
(0.00)\end{array}$ & $\begin{array}{l}4.00 \\
(0.00)\end{array}$ & $\begin{array}{l}3.25 \\
(0.91)\end{array}$ & $\begin{array}{l}3.95 \\
(0.22)\end{array}$ & $\begin{array}{l}3.50 \\
(0.76)\end{array}$ & $\begin{array}{l}1.75 \\
(1.02)\end{array}$ & $\begin{array}{l}3.90 \\
(0.31)\end{array}$ & $\begin{array}{l}3.90 \\
(0.31)\end{array}$ & $\begin{array}{l}3.90 \\
(0.31)\end{array}$ & $\begin{array}{l}3.10 \\
(1.29)\end{array}$ & $\begin{array}{l}3.85 \\
(0.37)\end{array}$ \\
\hline & $\begin{array}{l}3 \text { to } 5 \\
(\mathrm{n}=18)\end{array}$ & $\begin{array}{l}\text { Mean } \\
\text { (SD) }\end{array}$ & $\begin{array}{l}3.22 \\
(0.55)\end{array}$ & $\begin{array}{l}3.44 \\
(0.51)\end{array}$ & $\begin{array}{l}3.17 \\
(0.71)\end{array}$ & $\begin{array}{l}3.78 \\
(0.43)\end{array}$ & $\begin{array}{l}3.78 \\
(0.43)\end{array}$ & $\begin{array}{l}2.17 \\
(0.71)\end{array}$ & $\begin{array}{l}2.56 \\
(0.62)\end{array}$ & $\begin{array}{l}2.89 \\
(0.96)\end{array}$ & $\begin{array}{l}1.00 \\
(0.77)\end{array}$ & $\begin{array}{l}3.06 \\
(0.73)\end{array}$ & $\begin{array}{l}3.06 \\
(0.73)\end{array}$ & $\begin{array}{l}3.17 \\
(0.86)\end{array}$ & $\begin{array}{l}2.06 \\
(0.87)\end{array}$ & $\begin{array}{l}2.61 \\
(0.50)\end{array}$ \\
\hline & $\begin{array}{l}6 \text { to } \\
(\mathrm{n}=26)\end{array}$ & $\begin{array}{l}\text { Mean } \\
\text { (SD) }\end{array}$ & $\begin{array}{l}3.96 \\
(0.20)\end{array}$ & $\begin{array}{l}3.96 \\
(0.20)\end{array}$ & $\begin{array}{l}3.58 \\
(0.50)\end{array}$ & $\begin{array}{l}3.85 \\
(0.37)\end{array}$ & $\begin{array}{l}3.88 \\
(0.43)\end{array}$ & $\begin{array}{l}2.81 \\
(0.85)\end{array}$ & $\begin{array}{l}3.35 \\
(0.56)\end{array}$ & $\begin{array}{l}3.15 \\
(1.16)\end{array}$ & $\begin{array}{l}1.58 \\
(0.81)\end{array}$ & $\begin{array}{l}3.92 \\
(0.27)\end{array}$ & $\begin{array}{l}3.81 \\
(0.49)\end{array}$ & $\begin{array}{l}3.81 \\
(0.40)\end{array}$ & $\begin{array}{l}2.54 \\
(1.24)\end{array}$ & $\begin{array}{l}3.35 \\
(0.56)\end{array}$ \\
\hline & $\begin{array}{c}\text { Total } \\
(\mathrm{n}=64)\end{array}$ & $\begin{array}{l}\text { Mean } \\
\text { (SD) }\end{array}$ & $\begin{array}{l}3.75 \\
(0.47)\end{array}$ & $\begin{array}{l}3.83 \\
(0.38)\end{array}$ & $\begin{array}{l}3.56 \\
(0.59)\end{array}$ & $\begin{array}{l}3.88 \\
(0.33)\end{array}$ & $\begin{array}{l}3.89 \\
(0.36)\end{array}$ & $\begin{array}{l}2.77 \\
(0.92)\end{array}$ & $\begin{array}{l}3.31 \\
(0.73)\end{array}$ & $\begin{array}{l}3.19 \\
(1.01)\end{array}$ & $\begin{array}{l}1.47 \\
(0.91)\end{array}$ & $\begin{array}{l}3.67 \\
(0.59)\end{array}$ & $\begin{array}{l}3.62 \\
(0.63)\end{array}$ & $\begin{array}{l}3.66 \\
(0.62)\end{array}$ & $\begin{array}{l}2.58 \\
(1.22)\end{array}$ & $\begin{array}{l}3.30 \\
(0.68)\end{array}$ \\
\hline \multirow[t]{4}{*}{ Normal } & $\begin{array}{l}10 \text { to } 12 \\
(\mathrm{n}=10)\end{array}$ & $\begin{array}{l}\text { Mean } \\
\text { (SD) }\end{array}$ & $\begin{array}{l}4.00 \\
(0.00)\end{array}$ & $\begin{array}{l}4.00 \\
(0.00)\end{array}$ & $\begin{array}{l}4.00 \\
(0.00)\end{array}$ & $\begin{array}{l}4.00 \\
(0.00)\end{array}$ & $\begin{array}{l}4.00 \\
(0.00)\end{array}$ & $\begin{array}{l}4.00 \\
(0.00)\end{array}$ & $\begin{array}{l}4.00 \\
(0.00)\end{array}$ & $\begin{array}{l}4.00 \\
(0.00)\end{array}$ & $\begin{array}{l}3.80 \\
(0.42)\end{array}$ & $\begin{array}{l}4.00 \\
(0.00)\end{array}$ & $\begin{array}{l}4.00 \\
(0.00)\end{array}$ & $\begin{array}{l}4.00 \\
(0.00)\end{array}$ & $\begin{array}{l}4.00 \\
(0.00)\end{array}$ & $\begin{array}{l}4.00 \\
(0.00)\end{array}$ \\
\hline & $\begin{array}{l}3 \text { to } 5 \\
(\mathrm{a}=30)\end{array}$ & $\begin{array}{l}\text { Mean } \\
\text { (SD) }\end{array}$ & $\begin{array}{l}4.00 \\
(0.00)\end{array}$ & $\begin{array}{l}4.00 \\
(0.00)\end{array}$ & $\begin{array}{l}4.00 \\
(0.00)\end{array}$ & $\begin{array}{l}4.00 \\
(0.00)\end{array}$ & $\begin{array}{l}4.00 \\
(0.00)\end{array}$ & $\begin{array}{l}3.77 \\
(0.43)\end{array}$ & $\begin{array}{l}3.90 \\
(0.31)\end{array}$ & $\begin{array}{l}3.40 \\
(0.68)\end{array}$ & $\begin{array}{l}2.53 \\
(0.57)\end{array}$ & $\begin{array}{l}3.70 \\
(0.54)\end{array}$ & $\begin{array}{l}3.90 \\
(0.31)\end{array}$ & $\begin{array}{l}4.00 \\
(0.00)\end{array}$ & $\begin{array}{l}3.93 \\
(0.25)\end{array}$ & $\begin{array}{l}3.70 \\
(0.47)\end{array}$ \\
\hline & $\begin{array}{l}6 \text { to9 } \\
(\mathrm{n}=40)\end{array}$ & $\begin{array}{l}\text { Mean } \\
\text { (SD) }\end{array}$ & $\begin{array}{l}4.00 \\
(0.00)\end{array}$ & $\begin{array}{l}4.00 \\
(0.00)\end{array}$ & $\begin{array}{l}4.00 \\
(0.00)\end{array}$ & $\begin{array}{l}4.00 \\
(0.00)\end{array}$ & $\begin{array}{l}4.00 \\
(0.00)\end{array}$ & $\begin{array}{l}3.88 \\
(0.34)\end{array}$ & $\begin{array}{l}4.00 \\
(0.00)\end{array}$ & $\begin{array}{l}4.00 \\
(0.00)\end{array}$ & $\begin{array}{l}3.70 \\
(0.46)\end{array}$ & $\begin{array}{l}4.00 \\
(0.00)\end{array}$ & $\begin{array}{l}4.00 \\
(0.00)\end{array}$ & $\begin{array}{l}4.00 \\
(0.00)\end{array}$ & $\begin{array}{l}4.00 \\
(0.00)\end{array}$ & $\begin{array}{r}4.00 \\
(0.00)\end{array}$ \\
\hline & $\begin{array}{l}\text { Total } \\
(\mathrm{n}=80)\end{array}$ & $\begin{array}{l}\text { Mean } \\
\text { (SD) }\end{array}$ & $\begin{array}{l}4.00 \\
(0.00)\end{array}$ & $\begin{array}{l}4.00 \\
(0.00)\end{array}$ & $\begin{array}{l}4.00 \\
(0.00)\end{array}$ & $\begin{array}{l}4.00 \\
(0.00)\end{array}$ & $\begin{array}{l}4.00 \\
(0.00)\end{array}$ & $\begin{array}{l}3.85 \\
(0.36)\end{array}$ & $\begin{array}{l}3.96 \\
(0.19)\end{array}$ & $\begin{array}{l}3.78 \\
(0.50)\end{array}$ & $\begin{array}{l}3.27 \\
(0.76)\end{array}$ & $\begin{array}{l}3.89 \\
(0.36)\end{array}$ & $\begin{array}{l}3.96 \\
(0.19)\end{array}$ & $\begin{array}{l}4.00 \\
(0.00)\end{array}$ & $\begin{array}{l}3.97 \\
(0.16)\end{array}$ & $\begin{array}{l}3.89 \\
(0.32)\end{array}$ \\
\hline
\end{tabular}

We looked at the static and dynamic balance functions concerning three age groups, 3-5, 6-9 and 10-12 years, and noted that while each group had a lower balance score compared to the healthy participants, there was an increase in their balance with age. Figure 1 explains the variation of the static balance in DS and normal children. It displays that normal children maintain a higher and steady static balance throughout the age range, while DS group is showing improvement of balance with age and getting relatively closer to healthy peers. The variation of dynamic balance in two groups with age is graphically displayed in figure 2, and it shows that while DS group is having a lower dynamic balance compared to the healthy group, both groups show an improvement of dynamic balance with age, even though DS group is getting closer to their healthy peers. 


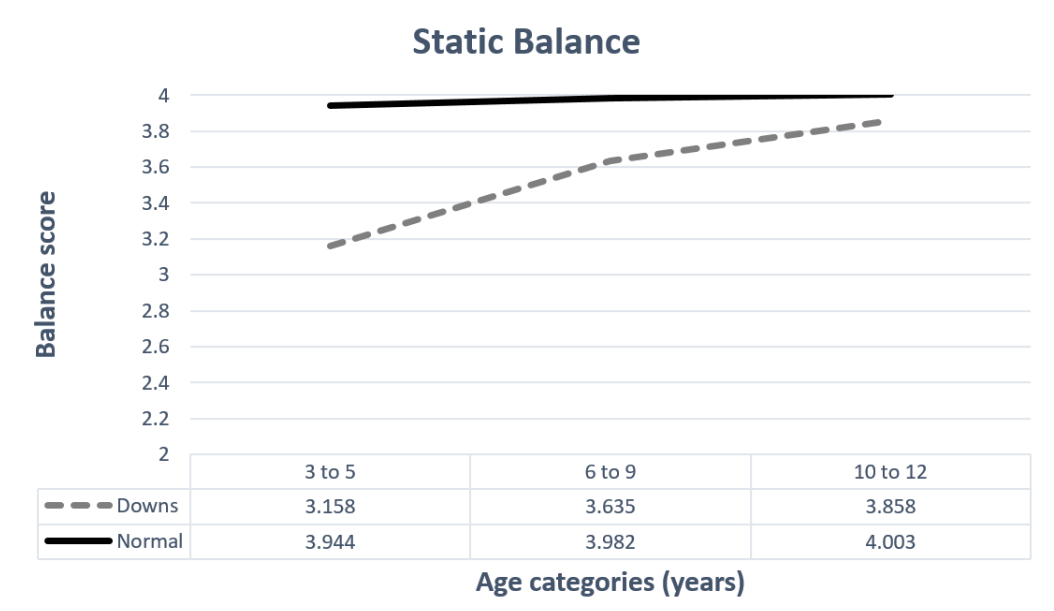

Figure 1: Static balance variation in downs and normal children across three different age groups

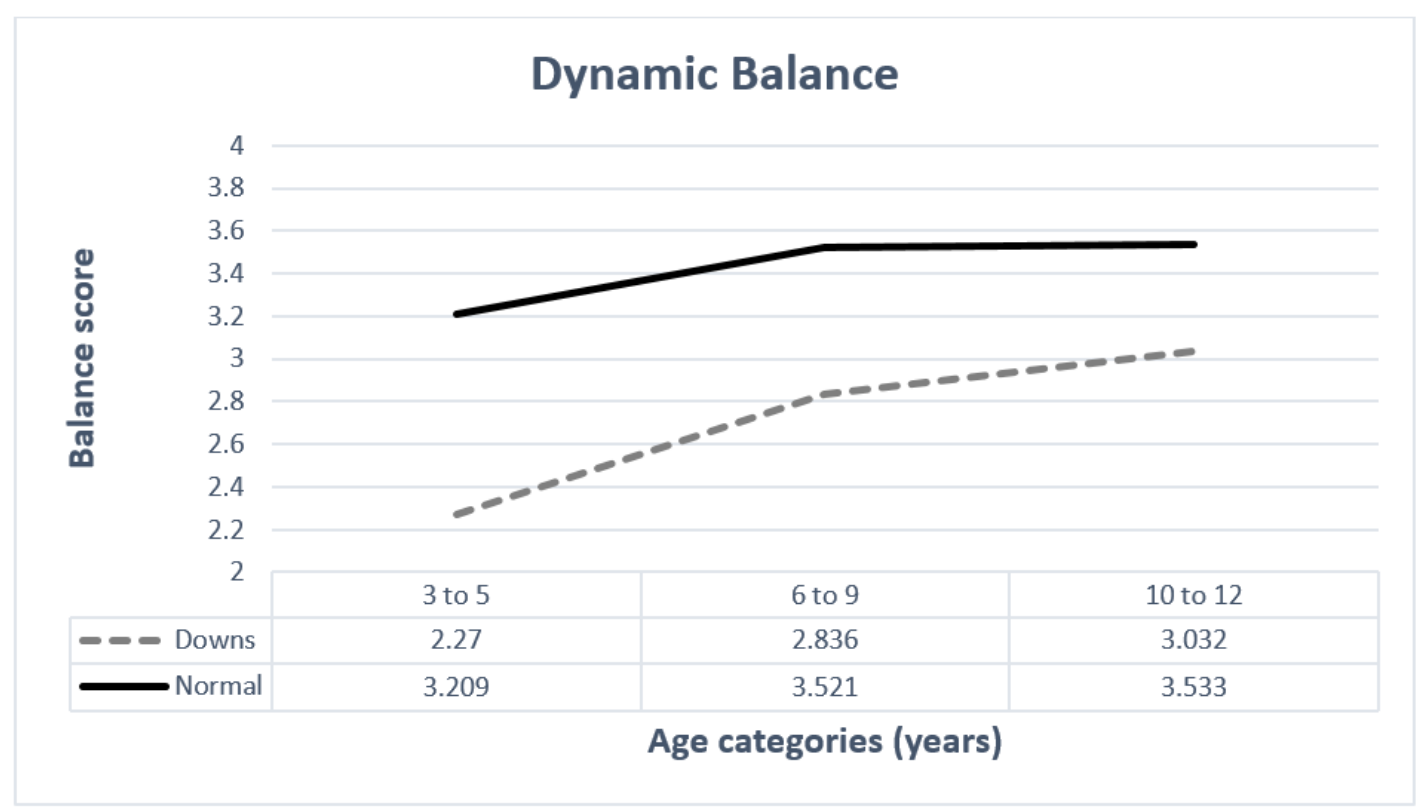

Figure 2: Dynamic balance variation in Downs and normal children across three different age groups

\section{Discussion}

The current study assessed the balance functions of DS children in comparison to age-matched healthy peers. Similar to past studies, the results demonstrated that DS children present poor balance functions compared to normal healthy children of the same age and that they performed significantly worse in dynamic balance skills ${ }^{19}$. Among the dynamic skills, standing on one leg and placing an alternate foot on a stool were highly affected while standing with eyes closed and reaching forward with outstretched arms were moderately affected. While the complexity of the task exacerbated balance difficulties, such as removing visual information, creating a small base of support and providing more cognitive demand, further, the DS itself has created a more challenging environment for gaining balance. Although children with DS exhibited poor postural control, it is interesting that their balance gradually improves with age and they become closer to their peers of same age.
Even though it was noted that the static balance of both groups is better compared to the dynamic balance skills, it is important to identify that the static score of the DS group was significantly less compared to that of the healthy group. Vuillerme et al. (2001) noted that the body sway of DS adolescents was significantly more than that of their normal peers pointing to a problem in overall balance $^{20}$. Wade et al. (2000), in their study revealed that DS teenagers continue to have greater sway than their normal peers ${ }^{21}$. The increased body sway activity may be due to increased cocontraction of antigravity muscles ${ }^{22}$. The above studies concluded that at rest the equilibrium is less stable in DS individuals than in their normal peers and this makes movement control less easy ${ }^{20,22}$. All the above evidence further strengthens the current study's finding of poor static balance in DS children. 
This study reports a significantly lower level of dynamic balance than static balance in DS children, similar to that reported in previous studies ${ }^{23,24}$. While dynamic balance functions are poor, relative to static skills among children with DS, there are specific skills that are remarkably affected. For instance, standing on one foot and placing an alternate foot on a stool show a lower balance score. Generally, there is more disturbance of posture when standing with the eyes shut than when standing with the eyes open ${ }^{9}$. However, the results suggest that this has become more challenging in DS. The poor performance while standing on one leg is due to a decreased proprioception sense in DS and low stability from the narrow base of support ${ }^{2}$. Other problems related to dynamic balance in DS include the postural control system, which results in poor dynamic balance, reasoning specific visuo-motor integration, and eye-hand coordination, combined with slow movement speed ${ }^{25}$. Children with DS adopt different dynamic postural control strategies and they tend to have a comparable centre of pressure displacement during dynamic balance tasks, including reaching conditions when compared to typically developing children ${ }^{1}$.

A group of researchers stated that DS children under the age of 6 years demonstrated deficits in the postural control system ${ }^{3}$. Our study findings revealed that while the balance in the three different age groups (3-5, 6-9 and 10-12 years) was poorer compared to healthy peers, at younger ages DS children have a poor balance which improves with age. This can be further explained by a study that revealed that postural synergies among young 22 month-old DS children that were not well organized improved when they reached 4 to 6 years of age ${ }^{3}$. In contrast, Jung and colleagues (2017) found that although the balance abilities of normal children improve with growth, in DS children there was no significant improvement in their balance, in spite of acquiring independent motor skills ${ }^{2}$. However in the current study, while the balance skills show an improvement with age, it is interesting to note that the balance gap between the normal and the DS groups also seems to narrow with age, indicating that children with DS become closer to healthy children with advancing age. This is an important finding, and the parents of children with DS need to be educated about this so that they will not lose motivation. This is also a valuable result for clinicians and allied health professionals when designing therapeutic interventions for children with DS.

The observational nature of the data in the present study presents a major limitation. While the current study advances our understanding of the balance variation of children with DS among different age groups, longitudinal studies to determine the improvement of balance with age especially in DS children are needed. Since the study was carried out only in the Colombo district, Sri Lanka, this was not a population-based sample. Thus the results of the present study cannot be generalized to the whole Sri Lankan DS population. Moreover, the study used a simple clinical measure of balance. Instead, a more reliable objective measurement of balance and postural control could be achieved using technologies such as force plates.

\section{Conclusions}

In this study balance skills of DS children were significantly less than their age matched normal peers. The dynamic aspects of balance were more affected than the static or transfer stability. In DS balance skills showed an improvement with age.

\section{Acknowledgements}

We are grateful to children and families who volunteered to participate in the study. Our special thanks extend to Lady Ridgway Hospital for Children, Chitra Lane School for the Special Child and Carey College, Colombo, Sri Lanka. We would like to acknowledge Ms. Lee Jones, Biostatistician of the Queensland University of Technology (QUT) and Dr. Martin Reese, Language \& Learning Skills Adviser, QUT.

\section{References}

1. Chen HL, Yeh CF, Howe TH. Postural control during standing reach in children with Down syndrome. Research in Developmental Disabilities 2015; 38:34551.

https://doi.org/10.1016/j.ridd.2014.12.024 PMid: 25590172

2. Jung HK, Chung E, Lee BH. A comparison of the balance and gait function between children with Down syndrome and typically developing children. Journal of Physical Therapy Science 2017; 29(1): 123-7.

https://doi.org/10.1589/jpts.29.123

PMid: 28210057 PMCid: PMC5300823

3. Shumway-Cook A, Woollacott $\mathrm{MH}$. Dynamics of postural control in the child with Down syndrome. Physical Therapy 1985; 65(9):1315-22. https://doi.org/10.1093/ptj/65.9.1315 PMid: 3162178

4. Malak R, Kotwicka M, KrawczykWasielewska A, Mojs E, Szamborski W. Motor skills, cognitive development and balance functions of children with Down 
syndrome. Annals of Agricultural and Environmental Medicine 2013; 20(4): 803-6.

5. Ulrich DA, Ulrich BD, Angulo-Kinzler RM, Yun J. Treadmill training of infants with Down syndrome: evidence-based developmental outcomes. Pediatrics 2001; 108(5):E84.

https://doi.org/10.1542/peds.108.5.e84

PMid: 11694668

6. Cratty B. Motor education and the education of retardates. Lea \& Feiger, Philadelphia. 1969.

7. Gutierrez-Vilahu L, Masso-Ortigosa N, Costa-Tutusaus L, Guerra-Balic M, ReyAbella F. Comparison of static balance on a platform in young adults with Down syndrome before and after a dance program. Adapted Physical Activity Quarterly 2016; 33(3):233-52.

https://doi.org/10.1123/APAQ.2015-0048 PMid: 27623608

8. Cardoso AC, Campos AC, Santos MM, Santos DC, Rocha NA. Motor performance of children with Down syndrome and typical development at 2 to 4 and 26 months. Pediatric Physical Therapy 2015; 27(2): 135-41.

https://doi.org/10.1097/PEP.00000000000 00120

PMid: 25695190

9. Galli M, Rigoldi C, Mainardi L, Tenore N, Onorati P, Albertini G. Postural control in patients with Down syndrome. Disability and Rehabilitation 2008; 30(17):1274-8. https://doi.org/10.1080/096382807016103 53

PMid: 17943512

10. Rigoldi C, Galli M, Mainardi L, Crivellini M, Albertini G. Postural control in children, teenagers and adults with Down syndrome. Research in Developmental Disabilities 2011; 32(1):170-5. https://doi.org/10.1016/j.ridd.2010.09.007 PMid:20933364

11. Association WM. World Medical Association Declaration of Helsinki. Ethical principles for medical research involving human subjects. Nursing Ethics 2002; 9(1):105.

12. Franjoine MR, Gunther JS, Taylor MJ. Pediatric balance scale: a modified version of the berg balance scale for the schoolage child with mild to moderate motor impairment. Pediatric Physical Therapy 2003; 15(2):114-28.

https://doi.org/10.1097/01.PEP.000006811 7.48023.18

PMid: 17057441

13. Branta C, Haubenstricker J, Seefeldt V. Age changes in motor skills during childhood and adolescence. Exercise and Sport Sciences Reviews 1984; 12(1):467520.

https://doi.org/10.1249/000036771984010 00-00015

PMid:6734680

14. de AC Duarte N, Grecco LAC, Franco RC, Zanon N, Oliveira CS. Correlation between Pediatric Balance Scale and functional test in children with cerebral palsy. Journal of Physical Therapy Science 2014; 26(6):849-53.

https://doi.org/10.1589/jpts.26.849

PMid: 25013281 PMCid: PMC4085206

15. Franjoine MR, Gunther JS, Taylor MJ. Paediatric balance scale: a modified version of the berg balance scale for the school-age child with mild to moderate motor impairment. Pediatric Physical Therapy 2003; 15(2):114-28.

https://doi.org/10.1097/01.PEP.000006811 7.48023.18

PMid: 17057441

16. Franjoine MR, Darr N, Held SL, Kott K, Young BL. The performance of children developing typically on the pediatric balance scale. Pediatric Physical Therapy 2010; 22(4):350-9. https://doi.org/10.1097/PEP.0b013e3181f9 $\mathrm{d} 5 \mathrm{eb}$

PMid: 21068635

17. Chen $\mathrm{Cl}$, Shen IH, Chen CY, Wu CY, Liu WY, Chung CY. Validity, responsiveness, minimal detectable change, and minimal clinically important change of Pediatric Balance Scale in children with cerebral palsy. Research in Developmental Disabilities 2013; 34(3):916-22.

https://doi.org/10.1016/j.ridd.2012.11.006 PMid: 23291508

18. Erdfelder E, Faul F, Buchner A. GPOWER: A general power analysis program. Behavior Research Methods, Instruments \& Computers 1996; 28:1-11. https://doi.org/10.3758/BF03203630 
19. Malak R, Kostiukow A, KrawczykWasielewska A, Mojs E, Samborski W. Delays in motor development in children with Down syndrome. Medical Science Monitor 2015; 21:1904-10.

https://doi.org/10.12659/MSM.893377

PMid: 26132100 PMCid: PMC4500597

20. Vuillerme N, Marin L, Debû B. Assessment of static postural control in teenagers with Down syndrome. Adapted Physical Activity Quarterly 2001; 18(4):417-33.

https://doi.org/10.1123/apaq.18.4.417

21. Wade MG, Emmerick R, Kernozek TW. Atypical dynamics of motor behaviuor in Down syndrome. Perceptual Motor Behavior in Down syndrome 2000: 277303.

22. Querner V, Krafczyk S, Dieterich M, Brandt T. Patients with somatoform phobic postural vertigo: the more difficult the balance task, the better the balance performance. Neuroscience Letters 2000; 285(1): 21-4.

https://doi.org/10.1016/S03043940(00)010 08-9
23. Chen HL, Yeh CF, Howe TH. Postural control during standing reach in children with Down syndrome. Research in Developmental Disabilities 2015; 38:34551. https://doi.org/10.1016/j.ridd.2014.12.024 PMid: 25590172

24. Meneghetti C, Blascovi-Assis S, Deloroso F, Rodrigues G. Static balance assessment among children and adolescents with Down syndrome. Brazilian Journal of Physical Therapy 2009; 13(3):230-5. https://doi.org/10.1590/S14133555200900 5000029

25. Marchal JP, Maurice-Stam H, Houtzager BA, Rutgers van Rozenburg-Marres SL, Oostrom KJ, Grootenhuis MA, et al. Growing up with Down syndrome: Development from 6 months to 10.7 years. Research in Developmental Disabilities 2016; 59:437-50.

https://doi.org/10.1016/j.ridd.2016.09.019 PMid: 27744268 